\title{
A human security analysis of the situation of girls and young women in KwaZulu-Natal, South Africa
}

\section{Christopher Isike ${ }^{1}$ and Kwame Owusu-Ampomah ${ }^{2}$}

\author{
${ }^{1}$ Politics and International Studies, University of Zululand, South Africa \\ isikec@unizulu.ac.za \\ ${ }^{2}$ Centre for Human Excellence and Development in Africa \\ Durban, South Africa \\ map.owusu@gmail.com
}

\begin{abstract}
Background: This paper is a product of a study which emanated from the need to get a nuanced understanding of the situation of young women in KwaZulu-Natal (KZN) in South Africa to inform evidence-based planning and programming. It aimed to analyse the lived experiences of girls and young women in the province focusing on broad questions around the challenges they face daily and interventions required to change their life circumstances in light of the socio-economic profile of the province. Conceptual themes were developed around the Human Security framework to contextualise the analysis.

Data and Methods: The study adopted a mixed methods approach in which qualitative and quantitative methods were combined for data collection and analysis. Quantitative data was collected from a randomly selected sample of 229 girls (aged 9-I7 years) and young women (aged I8 - 35) from four District Municipalities in KZN. The dataset was statistically analysed using the Statistical Package for Social Sciences (SPSS). Qualitative data was generated through in-depth interviews, involvng key stakeholders (I6); and focus group discussions (nine sessions). The qualitative dataset was thematically and hermeneutically analysed to generate insights into the lived experiences of the target population and policy implementation and outcomes.

Results and conclusion: The findings show that majority of the respondents have difficulty accessing reproductive health services available in the province. Also, they did not feel safe in their communities; there was also evidence in support of the abolition of harmful cultural practices such as Ukuthwala (forced marriage) and Ukuphelwa (female circumcision) which affect them. The paper concludes that it will be self-destructive for the provincial government to ignore the lived experiences of the respondents, which other studies show are not different from the lived experiences of girls and young women in the province who, alongside boys and young men of similar age cohort, constitute over $70 \%$ of the provincial population.
\end{abstract}

Key words: Girls, Young women; KwaZulu-Natal; Human Security; South Africa.

\section{Introduction}

South Africa ranks highly in Africa and the world for structural empowerment of women and children. Since 1994, women's issues have increasingly become integral to the government's development policy agenda; and women's visibility in the public sphere (government and business) has risen significantly'. The palpable political will to empower youths, realise gender equality and attain the MDG commitment of the South African state follows the pedigree of the ruling African National Congress (ANC) in addressing gender issues in the country. "The gendered transformation of the post-Apartheid South African social, economic and political space" (OwusuAmpomah, 20I I:I) is rooted in legislation, policies

http://aps.journals.ac.za and institutional mechanisms that aim to protect and empower women and children, and ensure gender equality and equity in all aspects of the nation's socioeconomic and political life. Equally commendable is "the progressive legislative framework to ensure de jure equality between women and men and the achievements in this regard..." (UN CEDAW, 20II:2). However, the legislations, policies and mechanisms have not in themselves prevented gender-based marginalization, oppression and violence against women especially in rural areas (see Goetz and Hassim, 2003; Isike and Uzodike, 2010; $20 \mathrm{Ila}$; 20l lb). Apart from concerns raised around uneven or inadequate resources and lack of capacity 
for the effective implementation of these policies and initiatives, there are other significant challenges which are widely documented ${ }^{2}$. Some of the challenges include the patriarchal dominance of society and the concomitant dangerous masculine behaviours, harmful cultural practices such as Ukuthwala (forced marriage) disproportionate HIV infection rates between men and women, especially among young women; teenage pregnancies and the continuous feminization of poverty. These are endemic at the provincial and municipal levels of government which are supposed to bring development closer to the people (Isike and Owusu-Ampomah, 2014).

Within the broad sphere of political, social, and economic marginalization and discrimination against women as a group, many (old and young, including even female babies) suffer sexual violence. Prevalence varies across provinces and rural communities in South Africa's municipalities and therefore intervention outcomes also differ (see KZN, DCSL, 20l0; Owusu-Ampomah, 201I). Inadvertently, the national focus of most nationwide studies such as the CEDAW Country Report tends to obscure the place-specific and demographic character of social problems and outcomes of interventions. The situation analyss of girls and young women in KwaZulu-Natal was therefore instructive; not only in shedding light on the region-specific nature of the problems and outcomes of strategic interventions but also meeting broader provincial and municipal governments' domestic and international obligations in regard to, for example, the Millennium Development Goals (MDGs) and its successor the Sustainable Development Goals (SDGs).

In this light, the purpose of this paper is threefold: First, to provide a socio-economic and political profile of young women and girls in KwaZulu-Natal province within a human security framework. Secondly, to determine and understand the factors that define the observed social, economic and political profile and, thirdly, to recommend appropriate policy and programmatic interventions to improve the quality of life of young women and girls in the province. The following broad research questions guided the paper within the conceptual framework of the human security paradigm of development:

- What is the demographic profile of girls and young women in 4 selected municipalities in KwaZulu-Natal?

- What are the key personal and community security and health challenges facing girls and young women in these municipalities?

- What interventions are necessary to support and create opportunities for this sub-population?
The next section outlines the human security paradigm as the theoretical framework of the paper; and this is followed by an outline of the methods and scope. The findings are presented and discussed under three of the seven themes that constitute the human security framework.

\section{Conceptual Overview}

The concept of human security has gained currency in global development discourse and practice since the beginning of the post-Cold War era. The increasing relevance of the concept is grounded in the multiplicity and enormity of human related challenges that continue to bedevil the world: safety from war and violence (nuclear threat); natural disasters, climate change, famine, epidemics, etc. States are realising the value of framing their development policies to meet the multiple human security needs of their peoples (see Africa, 2015).

Alkire (2003) attests to the observation that there are many competing definitions and characterisations of human security, as well as criticisms against the concept in the literature. In simple terms, human security entails the freedom of the individual from threats to physical safety to a decent quality of life and to human dignity. As correctly observed in the United Nations Development Programme's 1994 Human Development Report, New Dimensions of Human Security,

"...human security is people-centred because it concerns how people live and breathe in a society; how safely and freely they can exercise their many choices; how much access they have to market and social opportunities, whether they live in conflict or peace; how confident they can feel that the opportunities they enjoy one day will not be totally lost the next" (Fuentes and Aravena, 2005; cited in UNESCO, 2008: $3)$.

From this standpoint, UNESCO (2008: 3) equates human security with human rights. According to the organisation human security "comprises everything that is 'empowering' for individuals: human rights, including economic social and cultural rights, access to education and health care, equal opportunities, good governance, etc. This conception corresponds with the former Secretary General of the UN, Kofi Annan's definition of human security as "freedom from want, freedom from fear and freedom to live in dignity" (Annan, 2005:2) - a definition that underscores much of the seminal work of Amartya Sen, spanning over two decades, on human rights, 
human security, gender and development (e.g. see Sen, 1999, 2000, 200 la and 200 lb).

Doubtless true, human security is rooted in human rights. As an indicator of a state's ability to guarantee the rights of its citizens, it drives the state closer to ensuring the containment of threats to their security; and, thereby, entrenching the state's own legitimacy.
According to the UNDP (1994), threats to human security are encompassed within seven distinct areas of human existence: Economic security, environmental security, food security, political security, community, personal and health security (the last three of which are the focus of this paper).

\section{Table I: Elements of Human Security}

\section{Themes \\ Community security}

Economic security

\section{Environmental security}

Food security

Health security

\section{Personal security}

\section{Political security}

The human security paradigm thus prioritizes social and economic well-being, as well as the safety and security of all people (see Boutros-Ghali, 1992; Kaul, 1995; Tarry, 1999). The preservation and advancement of cultural and religious values, the promotion of social cohesion, access to job opportunities, food, education and other social services such as health care, water and sanitation, housing and electricity are highlighted as prerequisites for human security. Therefore, unlike the traditional notion which restricts security to the state, its institutions and their survival (see Booth, 199I; Buzan et al 1998; Waltz, 1999), the human security framework accommodates a wider range of issues that not only constitute threats to human existence, but also breed insecurity and societal anarchy. It views security from the perspective of human well-being and includes broad issues of human concern such as security from poverty, disease, famine, illiteracy, environmental despoliation, and unemployment, which singly or jointly, contribute to

\section{Description}

Protection of cultural and religious values, social cohesion.

Employment, basic income, access to social safety net, education and vocational training, protection against unemployment.

Access to water, freedom from environmental despoliation.

Access to basic food, quality of nutrition, share of household budget for food.

Access to healthcare systems and quality of care, access to safe and affordable family planning, prevention of HIV and AIDS, poor hygiene, teenage pregnancy, substance abuse and general well-being.

Safety from violent crime, all forms of physical abuse, rape and gender based violence based on sexual orientation

Civic participation, protection of human, women and girl's rights

the impairments of human existence (see Simpson, 2008; Isike, 2009). As noted earlier, human security places people at the centre of the security and development discourse and practice. It reinforces their human rights to protection from social, economic and political vulnerabilities that impair their existence in peace time, and also during wars and the immediate aftermath. Truly, vulnerabilities are exacerbated during and in the immediate aftermath of wars when existing socio-economic and political structures break down. However, security against war should only be part of a larger context in which human security is threatened. States should therefore not only focus on the narrow arena of war and conflict to secure their citizens but also do so in peace time, which even makes it possible to avert conflicts and wars, in the first place.

Scholars have argued that this kind of security rethinking should inform government attitude and policies towards development which, in the end, is all about people (Kaul, 1995; Tarry, 1999; Olonisakin, 
2015). In post-apartheid South Africa, for instance, where the gains that can be attributed to the cause of human security since the end of apartheid are significant (Africa, 20I5), some of these gains include the right to vote, basic education and primary health care; the introduction of an extensive social security system that has lifted many people out of poverty; the provision of affordable housing and basic services to millions (Africa, 20I5: 178). Nevertheless, Africa notes that, 20 years later "the country remains dogged by unemployment and poverty, structural inequality in the economy, the failure of some state institutions to provide adequately for the needs of all people, and failures in the criminal justice system" (Africa, 2015:179). She concludes that "human security has not prevailed, and might even be a waning value in the South African political and social fabric"; and wonders whether we are in fact "seeing a reversal of gains, and the return of the traditional security approach that had characterized the apartheid years" (Africa, 2015:178).

What analytical value does the human security paradigm hold for the girls and young women studied, and women generally? Within the peopleorientated approach to politics and development that defines the paradigm, it is possible to locate the gender question and interrogate which gender group is more vulnerable to human insecurities and why. In this light, feminist scholars such as Peterson (1992) have attempted to factor women into the human security discourse by contending that the narrow conceptualisation of security in traditional terms does more to decrease the security of women than to increase it. Also, because it focuses on people and their life circumstances, the human security paradigm opens space for a more inclusive discourse where not only can women participate directly, but can also demand and give effect to their human rights to life, work, good health, involvement in decision-making and remedy through active political participation (see CASS, 2005; Anderlini, 2007; Olonisakin, 20I5). The implication, therefore, is that human security and human rights are two sides of the development coin: a human security approach to development is rooted in human rights and the two reinforce each other. For instance, for poor women, the recognition that they have certain rights can be empowering, and demanding these rights from a people-centred government and getting a policy response represents a move towards development. Achieving development, attaining human security and respecting human rights is an ultimate goal for all societies; the extent to which this goal is being achieved specifically in regard to girls and young women in KwaZulu-Natal (and the underlying challenges) is the focus of this paper.

3182
Scope and Methods of Data Collection and Analysis

The study covered 4 of the II District Municipalities (DMs) in KwaZulu-Natal province; namely, EThekwini Metropolitan Municipality, Sisonke, Uthukela and Zululand. The decision to sample 4 out of the II DMs was taken by the joint task team that oversaw the study ${ }^{3}$. The determinants were twofold: (i) the 4 DMs were designated as part of the 9 priority districts earmarked by the KZN government and the UNFPA for special attention given the relatively high level of deprivation, particularly in the last three municipalities above, and in the larger context of KZN government's policy priority goals: reduction of poverty, inequality and unemployment, and (ii) resource constraints, including finance and time.

Apart from other stakeholders, such as public officials, academics/researchers and representatives of non-governmental organisations, the study essentially focused on girls aged 9- 17 years and young women aged 18-35 years, spread across different wards located in three environmental milieus - urban, peri-urban and rural - in the sampled districts.

The study adopted a mixed methods approach, i.e., a combination of quantitative and qualitative approaches in the collection and analysis of data. Instruments used included structured questionnaires and semi-structured interview schedules; both were respectively used for the collection of quantitative data in the survey of the sampled girls and young women and qualitative data through in-depth interviews and focus group discussions.

The questionnaires were administered by trained research assistants to collect primary data from a sample of 240 girls and young women ${ }^{4}$, aged 9-35 years. The sample was randomly selected across the four district municipalities (DMs). Of the 240 questionnaires administered, a total of 229 questionnaires were validated for analysis. The distribution was as follows: eThekwini Metro 50, Zululand 58, Uthukela 59 and Sisonke 62.

The simple random sampling technique has the advantage of providing equal chance of representation of a target population and also eliminating sampling bias. However, these advantages, as is widely documented, can hardly be guaranteed: populations are a tapestry of idiosyncrasies, all of which cannot be represented in a sample, save the population itself. Besides, sampling bias is inevitable in a relatively small sample, as in this case. This notwithstanding, the simple random sampling technique is not only much easier to use, compared to other sampling techniques such as snowball sampling or purposive sampling, but also 
time-saving; and this was true in the context of the referenced study.

The questionnaire was divided into eight sections to elicit biographical information on the sampled girls and young women, and the extent of their economic and food security, personal security, community security, health and environmental security and political security. Two additional sections sought to collect data on the challenges faced by the sampled girls and young women, and their perceptions of the government's response to those challenges. The questionnaire consisted of a mix of 74 closed-ended and open-ended questions. The latter allowed detailed responses from the respondents, which reflected their opinions on relevant issues and/or variables.

A sample of the questions on the key thematic areas or variables included in the questionnaires for the survey, depth interviews and focus group discussions are given below:

(i) What is your current employment status?

(ii) To what extent do you feel safe or not safe as a girl or young woman living in this community? Explain your answer.

(iii) To what extent do you agree or disagree with the proposition that "Ukuthwala" (bride abduction) should be abolished?

(iv) What kinds of violence have you ever experienced as a girl or young woman in this community or elsewhere in KwaZulu-Natal?

(v) Do you have access to reproductive health services in your community?

(vi) If "Yes" what are the services?

(vii) What personal health challenges do you face as a girl/young woman?(vii) What is the main source of water for you and your household?

The questionnaire and interview schedules were assessed by the sponsors and an external research advisory group of individual academics/researchers. The instruments were also piloted. The assessment and piloting of the questionnaire and interview schedules brought to the fore a few inconsistencies, ambiguities and issues of interpretation, which necessitated various kinds of adjustment of some of the questions. This approach helped to improve the (internal) validity of the questionnaire and interview schedules and reliability of measurements.

The sample was stratified by geography and disaggregated by key bio-data variables to reflect the demographic characteristics of the sample in the sampled district/metro municipalities.

The in-depth interviews and focus group discussions respectively targeted a select group of persons among the target population and some key stakeholders, including researchers/academics, public officials and representatives of local and international non-governmental organisations (NGOs). In all, 16 indepth interviews and nine Focus Group Discussions (FGDs) were conducted to counter-balance the weaknesses of the questionnaire approach, which invariably is a more useful tool for a snappy collection of statistical data, compared to other methods.

The key analytical methods for the qualitative data included content analysis, focusing on "the characteristics of language as communication with attention to the content or contextual meaning of the text" (Hsieh and Shannon, 2005: I278). Using various content analysis techniques such as interpretive analysis, themes and patterns were developed and coded from the qualitative data generated from responses to the open-ended questions, in-depth interviews and focus group discussions to identify and understand the threats and challenges facing girls and young women in the province. The analysis, in this respect, also paid attention to hermeneutic and heuristic analytical approaches, with the object of illuminating meanings and making sense of the lived experiences and stories of the sampled girls and young women, and the policy implications of those experiences and stories.

The quantitative dataset, on the other hand, was statistically analysed using the computer-based software, the Statistical Package for Social Sciences (SPSS), to generate descriptive and inferential statistics. In some instances, significance tests were conducted, using the Chi Square Test, to establish the veracity of relationships between variables. The Chi Square Test was preferred since it is more appropriate in instances where (i) the simple random sampling method is used, (ii) the variables are mostly categorical, and (iii) the expected value of the number of sample observations in each level of the variable is at least 5 . These conditions were satisfied in the referenced study.

\section{Limitations}

The cell sizes of some of the variables were found to be too small to permit meaningful comparative analyses; and this was particularly true of the data on population groups, hence the exclusion of analyses on racial differences. Thematic coding and categorisation of the qualitative data were also limited, not only by the adoption of UNDP's seven areas of threat but also to avoid oversimplification and the concomitant potential loss of detail, which might impact negatively on conclusions and possible policy choices.

\section{Findings}


Demographic profile of girls and young women in the sampled municipalities

The sample, disaggregated by key bio-data variables, as shown in Table 2, reflects the demographic characteristics of the sampled girls and young women in the four district/metro municipalities.

Table 21: Demographic characteristics of the sampled girls and young women

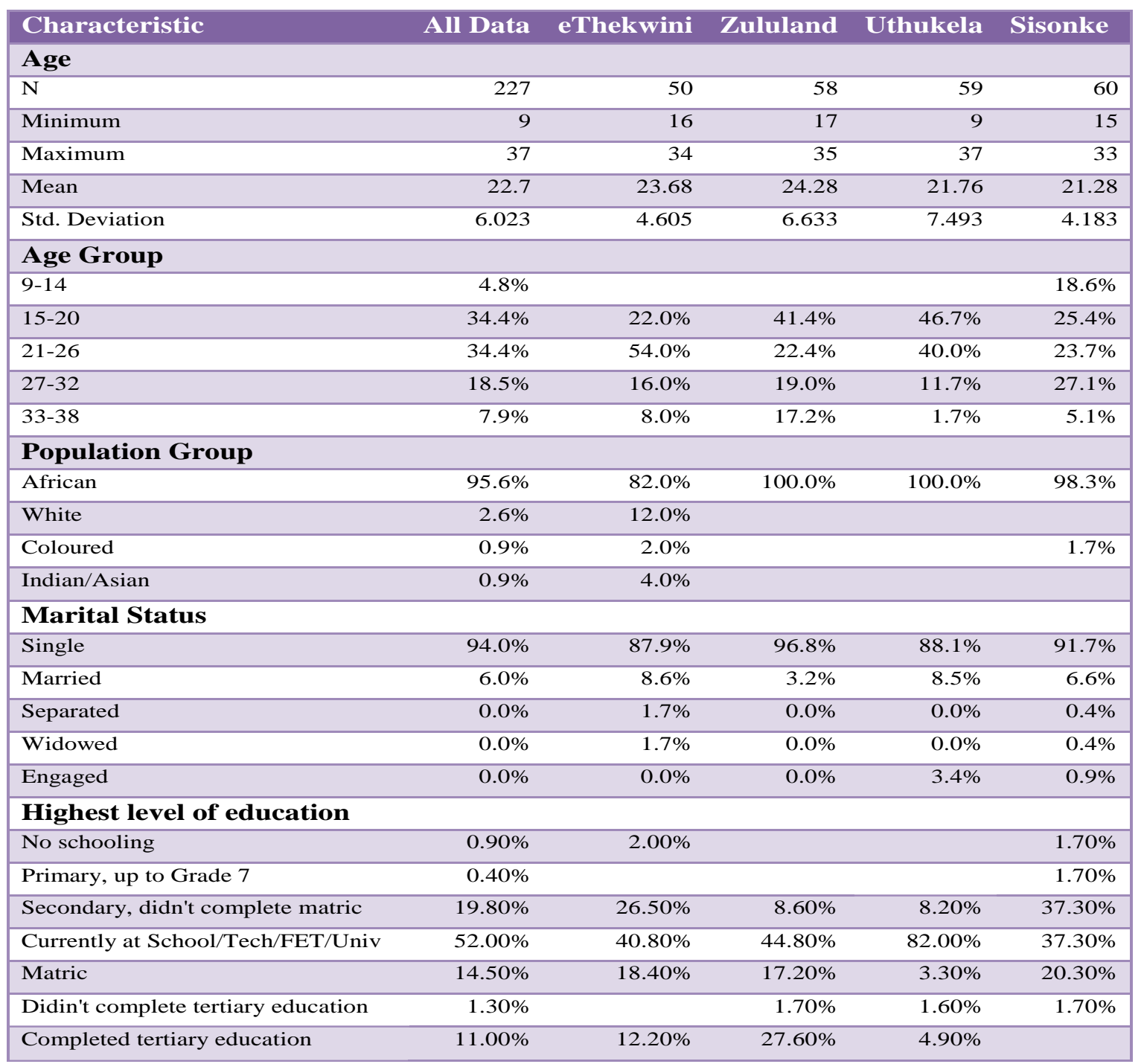

Majority (91.7\%) of the sampled girls and young women were single; only $6.6 \%$ were married, and the rest, in much smaller proportions, were either separated $(0.4 \%)$, widowed $(0.4 \%)$ or engaged $(0.9 \%)$. Sisonke had the highest proportion of respondents that indicated being single but this proportion was not statistically significantly different $(x=13.816 ; \quad d f=12 ; \quad p=0.313)$ from those in eThekwini, Uthukela or Zululand. Majority (95\%) was African and $20 \%$ of them had secondary education but didn't complete matric. As at the time of the study, a significant number $(52 \%)$ of them were studying at the tertiary level.

\section{Economic and food Security}

Employment status may have several connotations but the basic implication of being employed or selfemployed is financial independence, even if partial, which implies earning an income and having the capability to make choices (UNDP, 1990). This includes access to, at least, basic necessities of life, such as food, water, health services, shelter and education. Of the 223 girls and young women who reported on their employment status only one-infour $(24.2 \% ; n=54)$ reported being employed $(23.3 \%)$ or self-employed $(0.9 \%)$. Of the rest of the respondents (75.8\%; $n=169)$ who were unemployed, $50.2 \%$ were studying, a further $24.7 \%$ indicated that they were actively seeking work whilst $0.9 \%$ were not seeking work. 
Table 3: Employment Status by district/metro municipality, narrow definition ${ }^{5}$

\begin{tabular}{|llllll|}
\hline $\begin{array}{l}\text { District/Metro } \\
\text { Municipality }\end{array}$ & $\begin{array}{l}\text { e Thekwini } \\
\text { Metro }\end{array}$ & & & & \\
\hline Employed & $43.3 \%$ & $77.4 \%$ & $50.0 \%$ & $30.6 \%$ & $49.5 \%$ \\
\hline Unemployed & $56.7 \%$ & $22.6 \%$ & $50.0 \%$ & $69.4 \%$ & $50.5 \%$ \\
\hline Total & $100.0 \%$ & $100.0 \%$ & $100.0 \%$ & $100.0 \%$ & $100.0 \%$ \\
\hline
\end{tabular}

In a further analysis the results showed a relatively low but statistically significant $(X=15.292 ; d f=3$; $p=0.002)$ proportion $(22.6 \%)$ of the unemployed in Zululand compared to Sisonke (50\%), eThekwini Metro (56.7\%) and Uthukela (69.4\%). In other words, of the sampled girls and young women those in Uthukela were more likely to be unemployed than their counterparts in the rest of the sampled district municipalities. Unsurprisingly, nearly half $(47.2 \%)$ of the self-reporting unemployed girls and young women, reportedly depended on transfer payments, especially the Child Support Grant (96.3\%), for their livelihood.

\section{Personal and community security}

For majority of South Africans, a secured community, whether in a narrow or broad sense, is a cherished dream to realise. Respondents were asked about the extent to which they felt safe or not safe in their communities. In total, 7 of 10 respondents (69.2\%) indicated that they did not feel safe and secure in their communities; only $30.8 \%$ rated the level of safety and security in their communities as high. The geographical disaggregation of the data showed that respondents in Sisonke (84.1\%) were more likely $(X=10.458 ; d f=3 ; p=0.015)$ to report unsafe and insecure compared to respondents in eThekwini (78.6\%), Uthukela (63.6\%) and Zululand (55.6\%).

Figure I: Level of safety and security in community

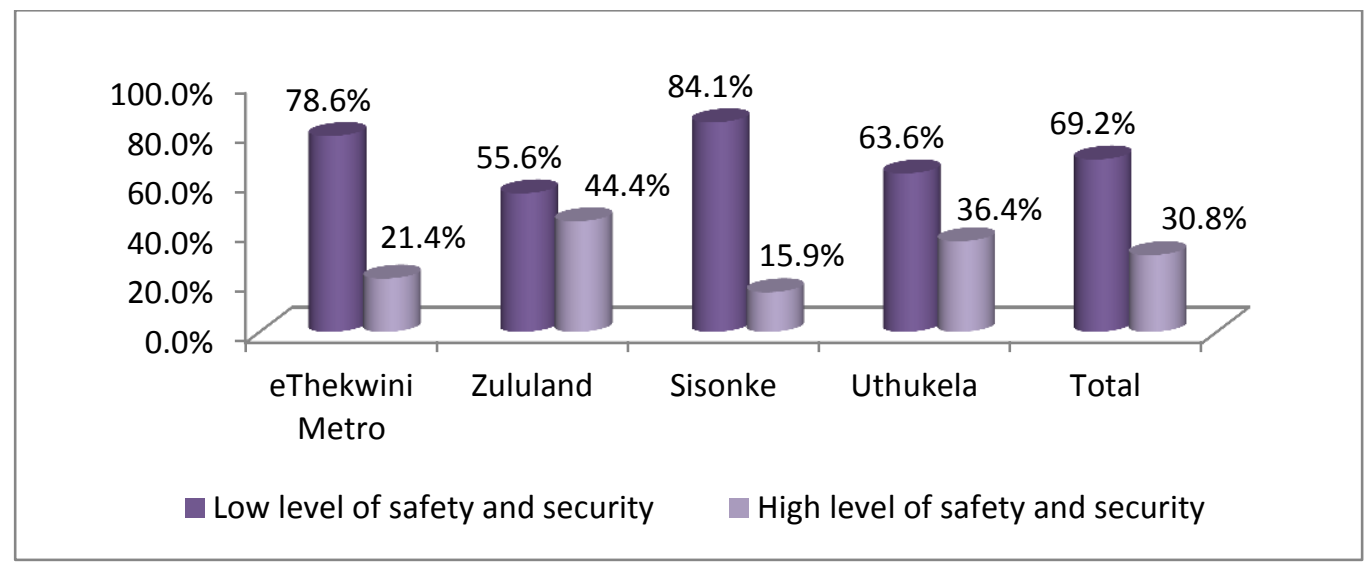

Across the sampled municipalities, the most common explanation offered by those respondents who felt unsafe and insecure in their communities was high crime rate (82\%). Expectedly, the highest proportion $(89.7 \%)$ of respondents who gave this reason was found in Sisonke. This proportion was, however, not significantly different from those of eThekwini (86.7\%), Zululand (77.8\%) and Uthukela (72.7\%). Other reasons that provide insights into the high crime rate include lack of policing (10.1\%), apathy towards crime, and alcohol and drug abuse (5.4\%). The latter is a major factor that contributes to crimes such as sexual abuse, housebreaking, mugging and physical violence ${ }^{6}$. Of the $30.8 \%$ who felt safe and secure, $85 \%$ attributed it to relatively low crime rates; $6 \%$ opted for "vigilant and caring community" while $9 \%$ indicated "taking personal responsibility for one's safety and security".

The respondents were asked about their experiences with gender-based violence either in their communities or elsewhere in KwaZulu-Natal. The kinds of violence experienced by at least two in five respondents included "hate speech/verbal abuse" (4I.8\%) and "harassment" (4I.6\%); one in four (25.7\%) indicated "bullying" (4I.6\%) and $20.0 \%$ cited "physical assault" (See Figure 2). 
Figure 2: Respondents who had experienced one form of violence or another by district/metro municipality

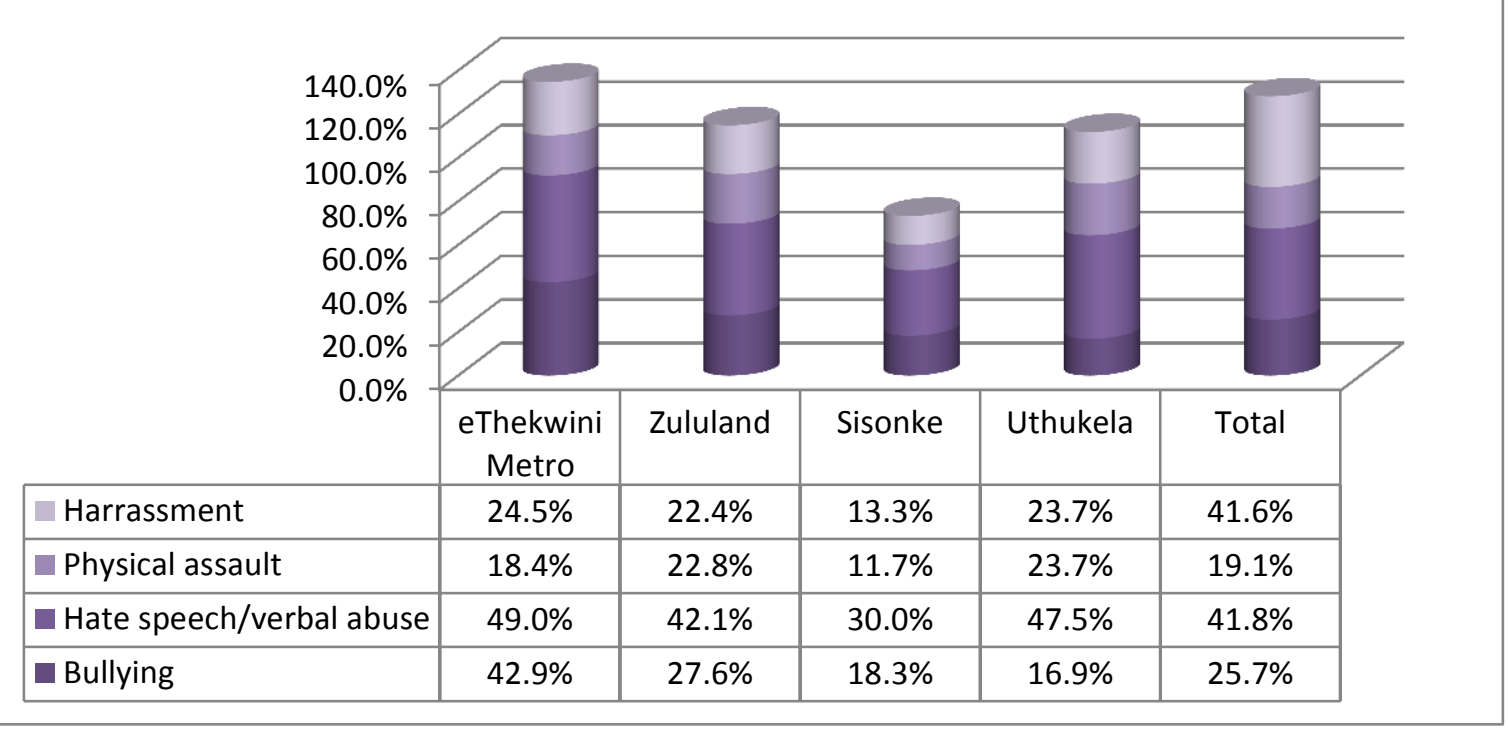

The study found that only $15.2 \%$ (22) of respondents reported incidents of violence against them to the police; a vast majority of them $(84.8 \%$; 123$)$ did not report. Within the district/metro municipality categories, the highest proportion that reported was in Sisonke $(25 \% ; n=6)$, and this proportion differed significantly $(x=8.682 ; d f=3 ; p=0.034)$, compare to those in Uthukela $(21.7 \% ; n=10)$, eThekwini $(15.2 \% ; n=5)$ and Zululand, which had the least proportion $(2.4 \% ; n=1)$ that reported to the police. The reasons for not reporting to the police varied widely, although most $(28 \% ; n=34)$ of the respondents reported that the incident was "too minor to report"; a further $20.7 \%(n=25)$ said justice was done whilst another $17.4 \%(n=21)$ indicated that they had no faith in the police. Explaining her position, one of the participants, Cebile (not her real name), asked, "What is the point in reporting to the police when they will make you feel it was your fault?" (Interview, 04/06/I4).

There were significant $(X=58.625 ; \quad d f=33$; $p=0.004)$ variations in the reasons prioritised by respondents in the district/metro municipality categories. For most of the respondents in eThekwini
(39.3\%; $\mathrm{n}=\mathrm{II})$ and Sisonke (38.9\%; $\mathrm{n}=7$ ) the reason for not reporting to the police was that "justice was done", although the proportion in eThekwini was somewhat higher than it was amongst the respondents in Sisonke. In contrast, while most (42.5\%; $n=17$ ) of respondents in Zululand did not report to the police because "justice was done" the highest proportion in Uthukela $(25.7 \% ; n=9)$ felt that it was enough to report to either their parents or teachers.

On issues of harmful cultural practices respondents were asked whether Ukuphelwa (female circumcision) should be abolished. A good proportion of the respondents $(71.1 \%)$ indicated "Strongly agree", implying that Ukuphelwa should be abolished.

In a related question, more than three quarters of the respondents $(75.8 \%)$ also strongly agreed that Ukuthwala (bride abduction) should be abolished. Of the 229 respondents II (5\%) domiciled in rural araes admitted that they had experienced Ukuthwala. A breakdown of the figure showed that seven were in Uthukela, two in Sisonke (now Harry Gwala) and two in

Zululand.

Table 4: Perceptions of Ukuphelwa (Female Circumcision) by District/Metro Municipality

\begin{tabular}{|llllll|}
\hline District/Metro Municipality & $\begin{array}{l}\text { eThekwini } \\
\text { Metro }\end{array}$ & Zululand & Sisonke & Uthukela & Total \\
\hline $\begin{array}{l}\text { Either disagree or strongly } \\
\text { disagree }\end{array}$ & $30.0 \%$ & $0.0 \%$ & $22.6 \%$ & $7.1 \%$ & $13.9 \%$ \\
\hline $\begin{array}{l}\text { Either agree or strongly } \\
\text { agree }\end{array}$ & $70.0 \%$ & $100.0 \%$ & $77.4 \%$ & $92.9 \%$ & $86.1 \%$ \\
\hline \begin{tabular}{l} 
Total \\
\hline
\end{tabular} & $100.0 \%$ & $100.0 \%$ & $100.0 \%$ & $100.0 \%$ & $100.0 \%$ \\
\hline
\end{tabular}




\section{Health Security}

In the context of the high prevalence of HIV and AIDS in KwaZulu-Natal, respondents were asked which in a list of reproductive health services they have access to. The results (Figure 3) show that the only health service that more than half of the sampled girls and young women have access to is "Contraceptives" (55.3\%). The next two services accessed by more than a quarter of the respondents were "Ante-natal services" (32\%) and "Diagnosis and treatment of STDs" (28.8\%). The three health services that were less frequently mentioned were "Seeing a gynaecologist" (I6.8\%), "mammogram/sonogram screening" (9.9\%) and "cervical cancer diagnosis" (8.6\%).

Figure 3: Proportion of respondents that have access to selected reproductive health services

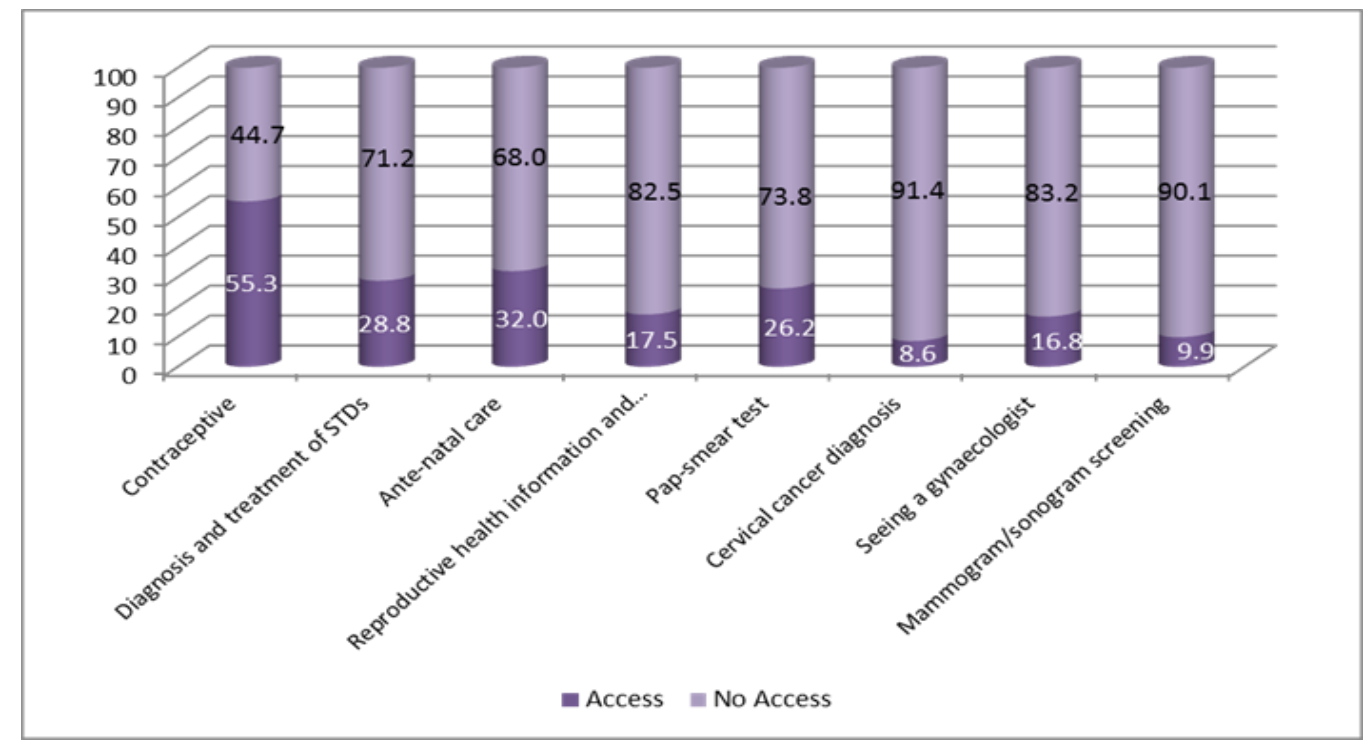

Interesting nuances were observed in the kinds of health services that respondents had access to in the district/metro municipality context. Majority of respondents in all the district/metro municipalities indicated having had access to contraceptives although the highest proportion was found in eThekwini (82.5\%). Statistically, this proportion was significantly $(x=27.185 ; d f=3 ; p=0.000)$ different from those among the respondents in Uthukela (62.7\%), Zululand (53.4\%) and Sisonke, which had the least proportion of respondents $(31.0 \%)$ that cited contraceptives.

The second most frequently mentioned health service was ante-natal care, accessed by $32 \%$ of the respondents. The highest proportion of respondents $(42.2 \%)$ that accessed this service was among the eThekwini Metro sub-sample but the proportion was not statistically significant $(x=2.735 ; \quad d f=3$; $\mathrm{p}=0.434$ ).

Diagnosis and treatment of STDs was chosen as the third health service, and was accessed by $28.8 \%$ of the sample. Within the district/metro municipality categories the highest proportion that selected this health service was found in Uthukela (40.7\%), andwas significantly higher than those among respondents in eThekwini (33.3\%), Zululand $(24.1 \%)$ and Sisonke, which again had the least proportion of respondents (18.3\%).

Table 5: Proportion of respondents that have access to selected reproductive health services by district/metro municipality

\begin{tabular}{|c|c|c|c|c|c|c|c|c|}
\hline Characteristic & $\begin{array}{l}\text { eThekwini } \\
\text { Metro }\end{array}$ & Zululand & Sisonke & Uthukela & Total & $\begin{array}{l}\text { Chi } \\
\text { Square }\end{array}$ & df & $\begin{array}{l}\text { P- } \\
\text { Value }\end{array}$ \\
\hline Contraceptive & $82.5 \%$ & $53.4 \%$ & $31.0 \%$ & $62.7 \%$ & $55.3 \%$ & 27.185 & 3 & 0.000 \\
\hline $\begin{array}{l}\text { Diagnosis and } \\
\text { treatment of STDs }\end{array}$ & $33.3 \%$ & $24.1 \%$ & $18.3 \%$ & $40.7 \%$ & $28.8 \%$ & 8.326 & 3 & 0.040 \\
\hline Ante-natal care & $42.2 \%$ & $29.8 \%$ & $29.5 \%$ & $28.8 \%$ & $32.0 \%$ & 2.735 & 3 & 0.434 \\
\hline $\begin{array}{l}\text { Reproductive health } \\
\text { information services }\end{array}$ & $32.6 \%$ & $15.8 \%$ & $14.8 \%$ & $10.2 \%$ & $17.5 \%$ & 9.908 & 3 & 0.019 \\
\hline
\end{tabular}




\begin{tabular}{|lllllllll|}
\hline Pap-smear test & $19.1 \%$ & $37.9 \%$ & $16.4 \%$ & $30.5 \%$ & $26.2 \%$ & 8.932 & 3 & 0.030 \\
\hline $\begin{array}{l}\text { Cervical cancer } \\
\text { diagnosis }\end{array}$ & $18.6 \%$ & $10.5 \%$ & $6.6 \%$ & $1.7 \%$ & $8.6 \%$ & 9.61 & 3 & 0.022 \\
\hline $\begin{array}{l}\text { Mammogram/sonogram } \\
\text { screening }\end{array}$ & $11.1 \%$ & $19.0 \%$ & $3.3 \%$ & $6.8 \%$ & $9.9 \%$ & 8.932 & 3 & 0.030 \\
\hline \begin{tabular}{l} 
Seeing a gynaecologist \\
\hline
\end{tabular} & $16.7 \%$ & $36.2 \%$ & $3.3 \%$ & $11.9 \%$ & $16.8 \%$ & 24.614 & 3 & 0.000 \\
\hline
\end{tabular}

Interestingly, the data showed statistically significant variations in the proportions of respondents in the to the spectrum of health services except ante-natal district/metro municipality categories that had access care where the $p$-value was found to be $>0.05$.

Table 6: Percentage of respondents who indicated having access to health services by age group

\begin{tabular}{|c|c|c|c|c|c|c|c|}
\hline Access to health services & $9-17$ & | 8-26 & $27-35$ & Total & $\begin{array}{l}\text { Chi } \\
\text { Square }\end{array}$ & df & $\begin{array}{l}\text { P- } \\
\text { Value }\end{array}$ \\
\hline Contraceptives & 35.6 & 53.6 & 74.6 & 55.6 & 16.103 & 2 & 0.000 \\
\hline $\begin{array}{l}\text { Diagnosis and treatment } \\
\text { of STDs }\end{array}$ & 17.4 & 23.5 & 48.3 & 29.0 & 21.061 & 4 & 0.000 \\
\hline Ante-natal care & 27.3 & 23.9 & 51.7 & 32.1 & 14.585 & 2 & 0.001 \\
\hline $\begin{array}{l}\text { Sexual and reproductive } \\
\text { health information }\end{array}$ & 8.7 & 14.7 & 30.0 & 17.6 & 9.584 & 2 & 0.008 \\
\hline Pap-Smear Test & 4.3 & 22.9 & 50.0 & 26.3 & 29.506 & 2 & 0.000 \\
\hline $\begin{array}{l}\text { Mammogram/sonogram } \\
\text { screening }\end{array}$ & 0.0 & 9.6 & 18.3 & 10.0 & 9.804 & 2 & 0.007 \\
\hline Cervical cancer diagnosis & 2.2 & 9.6 & 12.1 & 8.7 & 3.412 & 2 & 0.182 \\
\hline Seeing a gynaecologist & 8.7 & 13.2 & 30.5 & 16.9 & 11.124 & 2 & 0.004 \\
\hline
\end{tabular}

A further analysis focusing on the relationship between age group and access to health services showed statistically significant variations in the proportions among respondents in the age group categories that reported having access to all the health services except cervical cancer. In Table 32 the proportion of respondents that indicated having access to contraceptives in the 27-38 years age group is significantly higher than it is in the $18-26$ or the 917 years of age cohorts. Similarly, the proportion of respondents in the age group 27-38 that indicated having access to diagnosis and treatment of STDs is also significantly higher than it is in either the 18-26 or the 9-17 years of age cohort. This pattern is repeated in the rest of the data except cervical cancer where the variations between the age groups are not statistically significant $(p>0.05)$.

\section{Findings from Interviews and Focus Group Discussions}

The focus group discussions focused primarily on the challenges facing the sampled girls and young women. Like all girls elsewhere the sampled girls and young women in all the sampled DMs shared common aspirations, hopes and dreams for a better life but these, according them, were undermined by two key 3188 challenges: poverty and unemployment. This was succinctly elucidated by a participant who appeared to speak for all girls and young women in the province, and South Africa as a whole:

"Poverty is the main reason why we are unable to access further education, which to us, is a key factor in securing a good or well-paid job, become financially independent, be able to access services such as health care, piped (tap) water and electricity; secure a home and reduce our vulnerability to abuse and early pregnancy....

"Matric is not sufficient to get a job or a good job; our parents, especially our single mothers, lack money to help us pursue further studies. As a result, many of us roam about doing nothing ... and we get impregnated by men who exploit our vulnerability... This is the problem ....and we need help; our leaders must help us and stop being corrupt".

Whilst all the officials interviewed agreed with the sentiments expressed by the sampled girls and young women on the challenges facing them, most of them also believed that much of the problem of service delivery could be attributed to corruption and administrative bottlenecks in the planning and implementation of policies. On the issue of access to http://aps.journals.ac.za 
health care services, for example, a Ward Councillor explained that the health care facility in his area did not have the capacity to serve the increasing population of the area.

"The area requires a hospital," he said. "A mobile clinic is not sufficient, and besides, some areas don't have (piped, tap) water; reticulation of water and planning lack behind population growth and this is because the process of plan implementation is slow it's a major crisis".

Whilst the upgrading, and in some cases provision of facilities, are imperative, issues of personal and community safety and security were also a source of concern. There was a consensus amongst the sampled girls and young women, as well as interviewees that certain cultural practices, particularly ukhuthwala (bride abduction) and ukuphelwa (female circumcision) should be abolished. Not only were they perceived to be inhuman; they also violated the rights of girls and young women to dignity and freedom from bodily harm and emotional trauma.

\section{Discussion}

One of the key findings of the study was that economic challenges arise largely as a result of unemployment, which as widely documented, has not only become endemic but also affects women more than men. Only a quarter $(24.2 \%)$ of the 229 respondents was found to be employed, and in that situation they are compelled to rely on transfer payments, amongst other coping mechanisms. Nearly one in two $(47.2 \%)$ of the unemployed reportedly depended on social grants for their livelihoods, an overwhelming majority is on the child support grant. Transfer payments have been widely received as a positive intervention to alleviate social and economic pressures and even HIV and AIDs prevention, not only in KwaZulu-Natal and South Africa as a whole but also Sub-Saharan Africa, Latin America and the Caribbean (DSD, SASSA and Unicef, 2012; Stampini and Tornarolli, 20I2; UNDP, 20I4; UNICEF 20I5). Impliedly, unemployment and its attendant effects are definitive characteristics of the lives of girls and young women in the sampled municipalities and the province as a whole. This finding confirms the seriousness of economic security challenge posed by unemployment which cuts across and overlaps with other human security challenges that girls and young women face in the province. For example, the economic status of young women and their families impacts on their personal, food, health and community security, and the freedom to make choices.

Contextually, the findings presented show that two-thirds of respondents did not feel safe in their http://aps.journals.ac.za communities due to high crime rates and violence against women and this is supported in the literature (see). The findings also showed most victims of crime and abuse did not report to the police because they believed in the "justice" they got from alternative structures such as families, school authorities and other community stakeholders. However, there were those who did not report because they did not trust the police. Trusting 'alternative sources' of "justice" and not trusting the police, and thus the judicial system, is a cause for concern.

Relatedly, a vast majority of respondents $(86 \%)$ either "agreed" (15\%) or "strongly agreed" (71\%) that Ukuphelwa (female circumcision) should be abolished. Whilst a similar proportion (87\%) either agreed (II\%) or strongly agreed (76\%) that Ukuthwala (bride abduction) should be abolished only a few admitted to having experienced the cultural practice. Interestingly, respondents in Zululand were more likely to agree or strongly agree to the abolition of Ukuthwala than respondents in other sampled district municipalities. The finding in regard to Zululand was contrary to expectation considering that the practice of Ukuthwala was found to be more prevalent in Uthukela than Zululand. This observation may be explained in terms of normalisation of the practice in Uthukela and other sampled municipalities, compared to Zululand.

The finding that only a small number of respondents admitted to having experienced Ukuthwala appears to suggest that the practice is neither pervasive nor a huge challenge in the province but this might be far from reality. The fact is that respondents were reluctant to talk about it openly. The II respondents who admitted having experienced the cultural practice were not forthcoming with information. In another instance, a young woman who was interviewed on referral had several questions for the research team, wondering why anyone would nominate her for an interview on the subject when she had not complained to anyone, in the first place. This notwithstanding, the high proportion $(76 \%)$ of respondents that supported the abolition of Ukuthwala is indicative of not only its existence but also the magnitude of opposition to it.

These cultural practices which were seen to be functional in the past, have now not only become controversial but are also being abused, especially Ukuthwala. The perverse manifestation of Ukuthwala, even if not pervasive in the province, calls for concern especially in Uthukela and Sisonke district municipalities where young girls are sexually abused by boys "looking for sex". The original traditional practice of Ukuthwala has been problematized as human rights abuse and a violation of common law and the South African constitution 
(see Koyana and Bekker, 2007; Oosthuizen and Ngema, 2012; Mubangizi, 2012). Although Oosthuizen and Ngema (20I2) contend that there is a need for further research to evaluate Ukuthwala and if necessary acknowledge and develop it to be relevant in our constitutional democracy, majority of the respondents including victims strongly support its abolition. However, top-down legislation alone is unlikely to work; it is a culturally sensitive practice, and its abolition requires tact and community buy-in. We argue that any attempt to promote the rights and dignity of young women and girls "ought to recognise cultural diversity and adopt a more culturally sensitive style of discourse, including education and advocacy to eradicate "offensive" customs or prompt "positive deviation" (adoption of benign alternatives) rather than confrontation" (Owusu-Ampomah, 2013: II6).

In terms of access to health services, from a list of health services provided only one, "contraceptives", was accessed by more than half of the respondents (55\%). Two-thirds had access to ante-natal care (32\%) while $29 \%$ had access to "diagnosis and treatment of STDs"; "reproductive health information services" (18\%); "pap-smear test" (26\%); "cervical cancer diagnosis" (8.6\%) and "seeing a gynaecologist" (17\%). The reasonably high number of contraceptives use contradicts the findings on the number of girls who have children. However, the explanation is that those within the ages of 25 to 35 were more associated with using contraceptives than those below 25 years, especially the 9- 17 years of age cohort. This explains why teenage pregnancy remains a problem, and some attention needs to be focused on this age group in the promotion of contraceptives use. Clearly, low access to reproductive health services such as pap-smear and cervical cancer diagnosis is a problem. The barriers to accessibility of health care services have been widely documented and the list includes lack of health facilities, especially in rural and peri-urban areas, administrative bottlenecks, especially policy implementation constraints; lack of transport, lack of information, stigmatization and poor attitude of healthcare workers (see for example, Schierenbeck, Johansson, Andersson and Rooyen, 2013; Amnesty International, 20I4).

\section{Conclusion and Recommendations}

The focus of this paper has been on the challenges facing girls and young women in KwaZulu-Natal. The paper shows that in spite of the government's efforts to address the "Triple Threat" - poverty, inequality and unemployment - many girls and young women, still face a lot of challenges. The challenges cut across the entire spectrum of human security vulnerabilities. The primary challenge underlying the predicament of 3190 many girls and young women is two-fold: poverty and unemployment, around which several other challenges revolve: food inadequacy, inaccessibility of crucial social infrastructure such as education, health care services and safe drinking water. Besides there are also other human rights issues relating to personal and community safety of girls and young women in the context of harmful cultural practices such as Ukuthwala and Ukuphelwa; vulnerability to sexual violence, and other forms of crime. The challenges do not only undermine the promotion of gender equality and dignity of women, as well as the realisation of the wellbeing and human rights of girls and young women but also have a potential to precipitate socio-political discontent and instability.

On the basis of the reported challenges the following interventions are recommended:

- The Office on the Status of Women (OSW) may be strengthened to ensure effective coordination of programmes and activities of various departments and civil societies aimed at improving the quality of life of girls and young women in the province.

- Constant monitoring and evaluation of departmental programmes and projects targeting girls and young women in an effort to determine what is being done right, and what is being done wrong, and the learnings from such evaluations used to circumvent policy implementation constraints.

- Tackling policy implementation constraints should also include training street level bureaucrats and community workers (i.e., training the trainers) to inform and educate people on what government is doing and how they can maximize government support. This also includes gender awareness and sensitivity training for all public servants and law enforcement agents.

- Improving social mobilization and networking among girls and young women through community support groups and programmes to help them deal with some of the social challenges they face daily, especially in cases of gender abuse, sexual violence and harmful cultural practices, including Ukuthwala.

- Re-socialisation of boys and girls to help them start thinking and acting differently towards women since. Several psychologists (e.g., (Rummel, 1975; Berkowitz, 1989; Toch, 1993; Baumeister, et al, 1996) maintain that the psychology of violence is a function of self-perception of the situation or the Other.

- Empowerment of girls and young women on legal issues to help improve both access to justice and the quality of justice women receive. This may be done through legal education, legal aid services, support for non-discriminatory dispute-resolution 
fora; rights awareness campaigns (IDLO, 20I3) and state remedial institutions such as the Public Protector

Competing Interests: There are no competing interests. This paper is based on a study commissioned by the KwaZulu-Natal Department of Social Development (DSD) in collaboration with the KwaZulu-Natal Office of the Premier, UNFPA, UNICEF and UN Women, 20I3/I4. The task team that had oversight of the project was headed by a representative of the DSD which had responsibility for the final report.

\section{Author contributions:}

$\mathrm{Cl}$ was the Study Team Leader. He wrote the research proposal for the study, and led the data collection and analysis, and the writing process.

KO was the Principal Investigator of the study. $\mathrm{He}$ participated in the data collection, analysed the data and reviewed the proposal and the final report.

Both authors read and approved the final manuscript.

\section{Acknowledgements:}

We wish to acknowledge the immense contributions of the government task team led by Nolwazi Dlamini of the KwaZulu-Natal Department of Social Development, and supported by Linda Naidoo of the UNFPA. We appreciate all our respondents and also the role of our research assistants Fezile Ntuli, Khwezi Mapumulo, Smangele Ngema and Nompilo Dlamini.

\section{References}

Africa, S (2015) "Human Security in Africa". Strategic Review for Southern Africa, 37(I): 178 - 189.

Alkire, S. (2003) A Conceptual Framework for Human Security, Working Paper 2; Centre for Research on Inequality, Human Security and Ethnicity, CRISE Queen Elizabeth House, University of Oxford Retrieved from http://www3.qeh.ox.ac.uk/pdf/crisewps/workingp aper2.pdf on 06/05/2016.

Amnesty International (20I4) Struggle for Maternal Health Barriers to Antenatal Care in South Africa. Amnesty International, Retrieved on 24/05/2016 from https://www.health-e.org.za/wp content/uploads/2014/I0/Struggle-for-MaternalHealth-.pdf

Anderlini, S. N (2007) Women Building Peace: What They Do; Why It Matters. Boulder, CO: Lynne Rienner Publishers.

Annan, K (2005) "In Larger Freedom: Towards Development, Security and Human Rights for All”.
Report of the Secretary-General of the United Nations (A/59/2005).

Ayoob, M (1995) The Third World Security Predicament: State-making, Regional conflict and the International System. Boulder: Lynne Rienner

Baumeister, R., Smart, L. and Boden, J. (1996). "Relation of threatened egotism to violence and aggression: The dark side of self-esteem". Psychological Review, 103, 5-33

Bhana, D (2005). "Violence and the gendered negotiation of masculinity among young Black school boys in South Africa" In Ouzgane, $L$ and Morrell, R African Masculinities: Men in Africa from the late Nineteenth Century to the Present. Scottsville: University of KwaZulu-Natal Press

Booth, K, (199I) "Security in Anarchy: Utopian Realism in Theory and Practice" International Affairs, 67(3), 572 - 45

Boutros-Ghali, B, (1992) An Agenda for Peace: Preventive diplomacy, Peace-making and Peacekeeping, New York: United Nations.

Bruce, J. (2007) "Orphans and Vulnerable Children: The Girls Left Behind: Out of the Box and Out of Reach." Presentation at OVC IATT Meeting April 24, 2007, Office of the US Global AIDS Coordinator, Washington DC. from http://www.unicef.org/aids/files/The_Girls_Left_B ehind_-Judith_Bruce\%28I\%29.pdf (Accessed $31 / 03 / 2014$ ).

Buzan, B, Ole, W and Wilde, J (1998) Security: A New Framework for Analysis (Boulder: Lynne Rienner Publishers

Department of Health (20I2). The 20II National Antenatal Sentinel HIV \& Syphilis Prevalence Survey in South Africa. Pretoria: Department of Health

DSD, SASSA and UNICEF. (20I2). The South African Child Support Grant Impact Assessment: Evidence from a survey of children, adolescents and their households Pretoria: UNICEF South Africa. Retrieved on 17/05/2016 from http://www.unicef.org/southafrica/SAF_resources csg2012s.pdf

Fuentes, C. F. and Aravena, F. R. (2005). Promoting Human Security: Ethical, Normative and Educational Frameworks in Latin America and the Caribbean Paris, UNESCO.

Goetz, A.M and Hassim, S (2003) "In an against the party: women's representation and constituency building in Uganda and South Africa" In Molyneux, $M$ and Razavi, S (eds.) Gender Justice, Development and Rights, Oxford: Oxford University Press

Hsiu-Fang, H. and Shannon, S. E. (2005) Three Approaches to Qualitative Content Analysis 
Qualitative Health Research, Vol. I5 No. 9, pp. |277-I 288

Human Rights Watch (200I) "Scared at School: Sexual Violence in South African Schools". New York: Human Rights Watch (HRW).

International Development Law Organisation (IDLO) (2013) Accessing Justice: Models Strategies And Best Practices on Women's Empowerment, https://www.cimicweb.org/cmo/afg/Documents/G overnance/WomenAccessto]ustice.pdf (Accessed 29/03/20I4).

Isike, C and Alokwu, O (2010) "A Theological Response to the Human Security Challenges of the Niger-Delta Region of Nigeria". Journal of Theology for Southern Africa I38: 19 - 35.

Isike, C and Okeke-Uzodike, N (20 I la) "Towards an Indigenous Model of Conflict Resolution: Reinventing Women's Roles as Traditional Peacebuilders in Neo-colonial Africa". African Journal on Conflict Resolution II(2): 32 - 58.

Isike, C. and Okeke-Uzodike, N (20l lb) "Marginalising women in politics: recent trends in KwaZulu-Natal". Development Southern Africa Vol.28, No. 2, pp. 225-240.

Isike, C (20I2), "What do men think? The role of cultural (mis)conceptions in perpetuating male violence against women in neo-colonial Africa". In Freedman, J (ed.) Engaging Men in the Fight against Gender-Based Violence: Case Studies from Africa. United Kingdom: Palmgrave Macmillan.

Isike, C and Owusu-Ampomah, K (2014) A Situation Analysis of Girls and Young Women in KwaZuluNatal, South Africa. Final report of a study commissioned by the Department of Social Development (DSD) in collaboration with the UNFPA and UN Women in South Africa.

Kaul, I (1995) "Peace needs no weapons: from military security to human security", Ecumenical Review 47(3), 313-319.

Koyana and Bekker (2007) "The indomitable Ukuthwala custom". De Jure, I 39

KZN Department of Community Safety and Liaison (2010). Preventing Sexual Violence in KwaZuluNatal. Pietermaritzburg: Department of Community Safety and Liaison

Mubangizi, J. C. (20I2) "A South African Perspective on the Clash between Culture and Human Rights, with Particular Reference to Gender-Related Cultural Practices and Traditions". Journal of International Woman's Studies, Vol. 13 No. 3, pp. 33-48.

Olonisakin, F (20I5) Re-conceptualizing leadership for effective peacemaking and human security in Africa
Oosthuizen, T and Ngema, N (2010). "Ukuthwala: structured for relevance" Speculum Juris 2, 84 102

Owusu-Ampomah, K (20II) KwaZulu-Natal Gender Profile. Report commissioned by the KwaZuluNatal Office of the Premier, KwaZulu-Natal Provincial Government, Pietermaritzburg, KwaZulu-Natal

Owusu-Ampmah, K (20I3) The Rights and Wellbeing of Children in KwaZulu-Natal: A Situation Analysis. Research report commissioned by the KwaZulu-Natal Office of the Premier, KwaZuluNatal Provincial Government, Pietermaritzburg, KwaZulu-Natal, South Africa.

Panday, S., Makiwane, M., Ranchod, C., \& Letsoalo, T. (2009). Teenage pregnancy in South Africa with a specific focus on school-going learners. Child, Youth, Family and Social Development. Pretoria: Department of Basic Education

Peterson, S, (1992) Feminist (Re)Visions of International Relations Theory, Boulder: Lynne Rienner

Simpson, I (2008) "The paradox of resource wealth and human insecurity: reflections on the NigerDelta area of Nigeria" Africa Insight 38(2) (September), 62-76.

Stampini, M. and Tornarolli, L. (20I2) The Growth of Conditional Cash Transfers in Latin America and the Caribbean: Did They Go Too Far? CEDLAS, Universidad Nacional de la Plata Policy Paper No. 49 November 2012. Retrieved on 19/06/2016 from http://ftp.iza.org/pp49.pdf

Republic of South Africa (2009) South African CEDAW Report: Progress made on the implementation for the period $1998-2008$

Rummel, R. J (1975) Understanding Conflict and War: The Dynamic Psychological Field Volume I: California: Sage Publications. http://www.hawaii.edu/powerkills/NOTE I0.HTM \#CHAP (Accessed I4/0I0/2013)

Sen, Amartya K. 1999. Development As Freedom. New York: Knopf Press.

Sen, Amartya K. 2000. "Why Human Security?" Text of presentation at the "International Symposium on Human Security" in Tokyo, 28 July, 2000.

Sen, Amartya K. 1982a. "Rights and Agency." Philosophy and Public Affairs. II:I. 5-29.

Sen, Amartya K. 1982b. "The Right Not To Be Hungry.” In G Floistad, Ed. Contemporary Philosophy. II. The Hague: Martinus Nijhoff

Sen, Amartya K. 1985a. "Well-Being Agency and Freedom: The Dewey Lectures 1984." Journal of Philosophy. 82:4. 169-22I.

Sen, Amartya K. 1985c. "Rights and Capabilities." In T. Honderich, Ed. Morality and Objectivity. London: Routledge. I30-I48. 
UNDP (2014) Discussion Paper: Cash Transfers and HIV Prevention; United Nations Development Programme, One United Nations Plaza, New York, NY 10017, USA

UNICEF and EPRI (20I5) HIV-Sensitive social protection policy brief: Social Protection programmes contribute to HIV prevention. Available at: https://transfer.cpc.unc.edu/wpcontent/uploads/2015/09/SocialProtectionHIVBrie f」an20 I5.pdf (Accessed: I6 December 2016)

\footnotetext{
' South Africa has improved from less than $2 \%$ of women representation in national parliament in 1994 to $42 \%$ women representation in 2009. As of 2013 , South Africa is $8^{\text {th }}$ in global rankings and $4^{\text {th }}$ in Africa. Women in business boardrooms have also increased significantly to $24 \%$ (SADC Gender Protocol, 2010) while women constituted $41 \%$ of the workforce 10 years after democracy (De La Rey, 2005).

${ }^{2}$ See for example CEDAW Country Report 2011 and the National Status of the Youth Report

3 The task team comprised the research team and representatives of the sponsors of the study (KwaZuluNatal Department of Social Development (KZN DSD) and United Nations Population Fund (UNFPA), Pretoria.

${ }^{4}$ The coordinating task team agreed on uniformity in the number of respondents across the 4 DMs $(60 \times 4=240)$

, 5 Using a broad definition of unemployment, which includes the "Unemployed, not seeking work" but excludes those "Studying" in the computation, did not significantly affect the outcome of the data analysis and the significance level.

${ }^{6}$ This came out from the interviews which results show 10 of the 16 interviewees having similar positions on crime in their communities (interviews conducted
} 